\title{
Agricultural Feedstock Supplemented with Manganese for Biosurfactant Production by Bacillus subtilis
}

\author{
Jaqueline Matos $\mathrm{Cruz}^{1} \cdot$ Cian Hughes $^{2} \cdot$ Brid Quilty $^{3} \cdot$ Renato Nallin Montagnolli $^{1} \cdot$ \\ Ederio Dino Bidoia ${ }^{1}$
}

Received: 13 October 2016 / Accepted: 10 July 2017 / Published online: 12 July 2017

(C) Springer Science+Business Media B.V. 2017

\begin{abstract}
The greatest challenge in producing biomolecules at industrial scale is cost. In order to provide cheaper sources, the present study describes the production of biosurfactant using a low-cost medium supplemented with manganese. The feedstock used to produce biosurfactant was crude glycerol, a by-product of biodiesel production. Results showed that $5 \%(\mathrm{v} / \mathrm{v})$ of glycerol and $0.05 \mathrm{mM}$ of manganese was the best combination to produce biosurfactant. The produced biosurfactant was able to reduce surface tension and showed emulsification activity in diesel fuel. The main functional groups of the biosurfactant were identified by ${ }^{1} \mathrm{H}$ NMR and FTIR spectra. We identified the molecule as surfactin based on comparison with surfactin standard spectra described in the literature. This study showed conversion of low-value glycerol into valueadded products as biosurfactant. The use of a by-product as a carbon source for biosurfactant production is a possible strategy for reducing production costs. In addition, biosurfactant production by Bacillus subtilis can be considered safe and commercially viable, because it is a non-pathogenic bacterium.
\end{abstract}

Keywords Fermentation - Bioproducts - Agriculture · Glycerol $\cdot$ Biodiesel $\cdot$ Biofuels

Ederio Dino Bidoia

ederio@rc.unesp.br

1 Department of Biochemistry and Microbiology - Institute of Biosciences, São Paulo State University (UNESP), Av. 24-A, 1515, 13506-900 Rio Claro, Brazil

2 School of Engineering, Dublin City University (DCU), Dublin 9, Ireland

3 School of Biotechnology, Dublin City University (DCU), Dublin 9, Ireland

\section{Introduction}

Biosurfactants are complex biomolecules produced by bacteria and fungi. They have important properties including solubility, low critical micelle concentration (CMC) and surface tension reduction [1].

The industrial-scale production of biosurfactants must overcome some challenges, such as low yield, expensive substrates and downstream processing operations that increase production costs. The commercially available biosurfactant surfactin is valued at approximately $\$ 15.3 / 1 \mathrm{mg}$. On the other hand, the cost of chemical surfactants is around one dollar/lb, to put it in perspective [2]. Therefore, potential substrates for biosurfactant production have been sought from agro-industrial crops and residues, to provide cheaper and renewable sources for production at industrial scale.

Biodiesel is obtained from triglycerides by a transesterification reaction with methanol. The main by-product from biodiesel production is glycerol. The world biodiesel market might reach 37 billion gallons by 2016 [3]. Consequently, crude glycerol will be increasingly available. Therefore, conversion of this low-value glycerol into valueadded products have attracted attention.

The biosurfactant produced by Bacillus subtilis strains consists of a long-chain fatty acid linked in a short peptide moiety composed of seven amino acids. There are natural variations of the surfactin chemical structure [4]. The peptide sequence may change due to substitutions of amino acid in the peptide ring [5-7]. In addition, the length of the fatty acid chain can vary between 13 and 15 carbons [8-10] or least common homologous with 12 and 16 carbons [9, $11,12]$. These homologous can exhibit different properties and activities $[13,14]$. 
The species $B$. subtilis is able to grow in many alternative carbon sources, including agricultural waste and byproducts [15]. The supplementation of the medium with metallic ions may induce overproduction of surfactin. Manganese and iron salts added to the culture medium enhances both the biomass and surfactin concentration [16, 17].

This article describes the production of surfactin by B. subtilis in a medium with glycerol, a low-cost carbon source, supplemented with manganese salts. The properties of the crude surfactin such as surface tension and emulsification activity were tested. Chemical characterisation of the purified surfactin was obtained using Infrared spectra and ${ }^{1} \mathrm{H}$ NMR spectra.

\section{Materials and Methods}

\section{Growth Conditions of Bacillus subtilis}

Bacillus subtilis ATCC 6633 was grown in Erlenmeyer flasks with $50 \mathrm{~mL}$ of nutrient broth and $5 \%$ of glycerol. The medium was incubated on a rotary shaker at $180 \mathrm{rpm}$ and $35^{\circ} \mathrm{C}$ for $24 \mathrm{~h}$. Afterwards, the culture medium and the cells were separated by centrifugation for $20 \mathrm{~min}$ at $1500 \times \mathrm{g}$ using a K-24 centrifuge. The cells were washed with sterile sodium chloride solution $0.85 \%(\mathrm{w} / \mathrm{v})$. The inoculum was adjusted by measuring the optical density of $0.35 \times 10^{-1}$ $\left(1.66 \mathrm{~g} \mathrm{~L}^{-1}\right)$ at $600 \mathrm{~nm}$ and $1 \mathrm{~mL}$ was used to inoculate the production medium.

\section{Biosurfactant Production}

The culture medium for biosurfactant production was composed of $50 \mathrm{~mL}$ of Bushnell-Haas medium. Factors such as glycerol concentration (5, 7 and $9 \% \mathrm{v} / \mathrm{v})$ and manganese sulfate $\left(\mathrm{MnSO}_{4} \mathrm{H}_{2} \mathrm{O} 99.6 \%\right.$-Mallinckrodt) concentration were tested to allow higher productivity of biosurfactant. The $\mathrm{MnSO}_{4}$ was added to the medium to obtain concentrations of 0.01 and $0.05 \mathrm{mM}$. Bacterial growth was monitored by measuring the optical density at $600 \mathrm{~nm}$ (Hach DR/2500 Spectrophotometer). A calibration curve was built to relate the absorbance with cell dry weight. The $\mathrm{pH}$ of the production medium was measured after fermentation using a Digimed DMPH-2 $\mathrm{pH}$ meter. The flasks were incubated on a rotary shaker at $180 \mathrm{rpm}$ and $35^{\circ} \mathrm{C}$ for $72 \mathrm{~h}$. The production of dry crude biosurfactant was calculated using optimum conditions for biosurfactant production.

\section{Biosurfactant Extraction}

Bacillus subtilis cells were removed from culture medium by centrifugation at $1500 \times g$ for 20 min using a K-24 centrifuge. The cell-free supernatant was subjected to acid precipitation, according Cooper et al. [18]. by the addition of $6 \mathrm{M} \mathrm{HCl}$ until the $\mathrm{pH}$ reached $\mathrm{pH} 2.0$ and was stored at $4{ }^{\circ} \mathrm{C}$ overnight. Crude biosurfactant was recovered by centrifugation at $1500 \times g$ for $20 \mathrm{~min}$.

\section{Surface Tension Measurement}

Surface tension measurements were performed using a Krüss K6 Tensiometer equipped with a Du Noüy platinum ring. The crude biosurfactant was dissolved in a phosphate buffer $\mathrm{pH}$ 7. The surface tension was plotted against concentration of crude biosurfactant to determine the critical micelle concentration (CMC).

\section{Emulsification Index $\left(\mathbf{E}_{24}\right)$}

The ability of the biosurfactant to emulsify liquid such as water and oil fuel was tested. Emulsifying activity was determined by the addition of $2 \mathrm{~mL}$ of diesel fuel and the same volume of biosurfactant solution at different concentrations in test tubes. The tubes were then vortexed at maximum speed for $2 \mathrm{~min}$, and the emulsions produced were allowed to settle for $24 \mathrm{~h}$ at room temperature. The emulsification index $\left(\mathrm{E}_{24}\right)$ was calculated as the percentage of the height of the emulsified layer ( $\mathrm{mm}$ ) divided by the total height of the liquid column (mm) [19].

\section{Purification of the Biosurfactant}

Crude biosurfactant was purified by column chromatography filled with silica gel $0.03-0.2 \mathrm{~mm}, 60 \mathrm{~A}$ (Acros Organics). The silica was suspended in chloroform/methanol (2:1). The crude biosurfactant $(0.5 \mathrm{~g})$ was dissolved in chloroform/methanol (2:1). The column was eluted using solutions with increasing polarities. Chloroform $/ \mathrm{methanol} /$ ammonium hydroxide solution at a concentration of $28 \%$ (v/v) (80:20:4) (v/v/v), chloroform/methanol/ammonium hydroxide $28 \%(75: 25: 4)(\mathrm{v} / \mathrm{v} / \mathrm{v})$ and chloroform/methanol/ ammonium hydroxide $28 \%$ (65:35:5) [5]. Fractions were collected and the presence of biosurfactant was detected by thin layer chromatography with ninhydrin solution. The fractions containing the biosurfactant were placed in a flask and the solvent was evaporated under vacuum by a rotary evaporator. The purified biosurfactant was analysed by FT-IR and NMR spectroscopy.

\section{Characterisation with FT-IR Spectroscopy and Nuclear Magnetic Resonance (NMR)}

Fourier transform infrared spectroscopy FT-IR was used to determine the chemical nature of the biosurfactant. The main functional groups of biosurfactant were obtained using an FT-IR spectrometer Shimadzu 8300. 
The ${ }^{1} \mathrm{H}$ NMR spectra of biosurfactant were recorded on a Bruker $600 \mathrm{MHz}$ spectrometer at room temperature operating, 64 scans (with tetramethylsilane as internal standard). Thirty milligrams of purified biosurfactant were dissolved in $0.5 \mathrm{~mL}$ deuterochloroform $\left(\mathrm{CDCl}_{3}\right)$. The assignment of the peaks in the ${ }^{1} \mathrm{H}$ NMR spectra was done according to the literature $[8,9,17,20]$.

\section{Results and Discussion}

\section{Effect of Glycerol on Biosurfactant Production}

Bacillus subtilis growth in the medium with different concentrations of glycerol is shown in Fig. 1. Bacillus subtilis growth was reported in cell dry weight $\left(\mathrm{g} \mathrm{L}^{-1}\right)$ and the $\mathrm{pH}$ of the medium was measured after $48 \mathrm{~h}$ of incubation at $35^{\circ} \mathrm{C}$. The medium with $5 \%(\mathrm{v} / \mathrm{v})$ glycerol supported the best $B$. subtilis growth and the $\mathrm{pH}$ of the medium was around 6. Higher levels of crude glycerol affected growth and the $\mathrm{pH}$ of the medium negatively. The medium with 7 and $9 \%(\mathrm{v} / \mathrm{v})$ of glycerol strongly inhibited the B. subtilis growth. The $\mathrm{pH}$ of the medium decreased to around 4 and 5.

Glycerol is a molecule with a strong influence on the osmotic pressure within cells. High levels of glycerol in the medium can cause intracellular modifications in order to guarantee the bacterial adaptation exposed to unfavourable conditions [21]. Hence, in this study the concentration of glycerol greater than $5 \%$ in the medium prevented the bacterial growth.

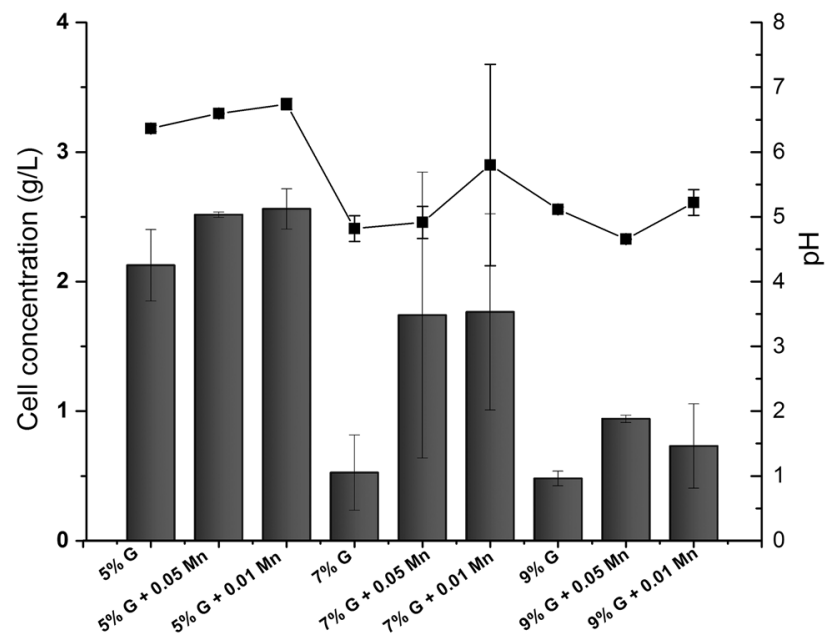

Fig. 1 Bacillus subtilis growth in medium with different concentrations of glycerol and manganese (grey bar). Measurement of $\mathrm{pH}$ value of medium after $72 \mathrm{~h}$ (filled squared with solid line). Error bars values of three independent experiments
The results showed that the addition of 0.01 or $0.05 \mathrm{mM}$ of $\mathrm{MnSO}_{4}$ in the medium increased microbial growth in all glycerol concentrations, especially in samples with $5 \%$ of glycerol. The cell dry weight reached $2.13 \mathrm{~g} \mathrm{~L}^{-1}$ in medium with glycerol $5 \%(\mathrm{v} / \mathrm{v})$ while the samples with 0.01 and $0.05 \mathrm{mM}$ of $\mathrm{MnSO}_{4}$ reached 2.56 and $2.52 \mathrm{~g} \mathrm{~L}^{-1}$, respectively. Therefore, there was no difference in the $B$. subtilis growth between 0.01 and $0.05 \mathrm{mM}$ of $\mathrm{MnSO}_{4}$.

\section{Crude Biosurfactant Production}

High glycerol concentrations $(9 \% \mathrm{v} / \mathrm{v})$ did not allow growth of the $B$. subtilis. Consequently, it was not possible to recovery any biosurfactant. At the concentrations of 7 and $5 \%(\mathrm{v} / \mathrm{v})$, the amount of crude biosurfactant produced was 26 and $146 \mathrm{mg} / \mathrm{L}$, respectively. Sousa et al. [22] also used $5 \%$ of glycerol in the medium to produce biosurfactant with different strains of Bacillus. The acid $\mathrm{pH}$ value of the medium at 7 and $9 \%$ of glycerol probably interfered with the recovery of biosurfactant because the biosurfactant is not soluble under acidic conditions [15].

The amount of dry crude biosurfactant was highest in the medium containing $\mathrm{MnSO}_{4}$. The medium at $5 \%$ of glycerol supplemented with 0.01 and $0.05 \mathrm{mM}$ of $\mathrm{MnSO}_{4}$ produced 740 and $793 \mathrm{mg} \mathrm{L}^{-1}$ of crude biosurfactant, respectively. The manganese plays an important role in the surfactin production, because it improves nitrogen metabolism as it promotes synthesis of free amino acid required for surfactin production [23, 24].

Although manganese salts improve the surfactin production, the combination of glycerol and manganese can promote biofilm-associated sporulation [25]. For this, it is important to know which concentration of glycerol and manganese is the best for biosurfactant production. In this study, the addition of $0.05 \mathrm{mM}$ of $\mathrm{MnSO}_{4}$ improved the biosurfactant production significantly.

The medium with $5 \%$ glycerol supplemented with 0.01 and $0.05 \mathrm{mM} \mathrm{MnSO}_{4}$ achieved superior production when compared with production from a synthetic medium. Al-Wahaibi et al. [26] used B. subtilis to produce biosurfactant in minimal medium with different sources of carbon. The yield in minimal medium with glucose and molasses was 300 and $500 \mathrm{mg} \mathrm{L}^{-1}$ of biosurfactant, respectively. Liu et al. [14] obtained $692 \mathrm{mg} \mathrm{L}^{-1}$ of biosurfactant from LB medium. In this work, the use of a low cost co-product as a source of carbon achieved a maximum production of $793 \mathrm{mg} \mathrm{L}^{-1}$. Therefore, the use of this carbon source might be able to reduce the production costs of the biosurfactant. 


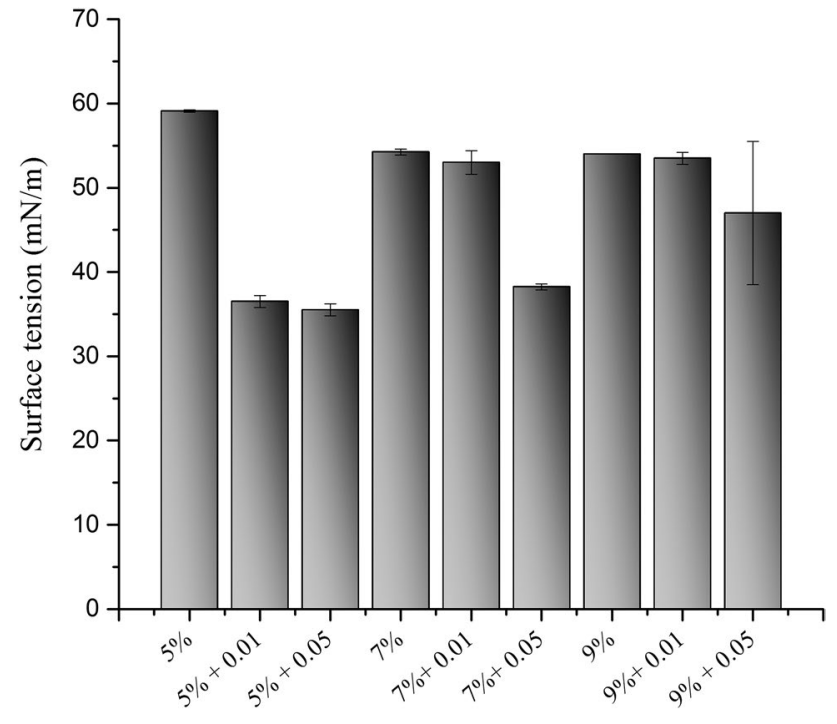

Fig. 2 Surface tension values $\left(\mathrm{mN} \mathrm{m}^{-1}\right)$ obtained in the medium at 5,7 and $9 \%$ (v/v) glycerol after $72 \mathrm{~h}$ of incubation. The medium was supplemented with 0.01 and $0.05 \mathrm{mM} \mathrm{MnSO}_{4}$

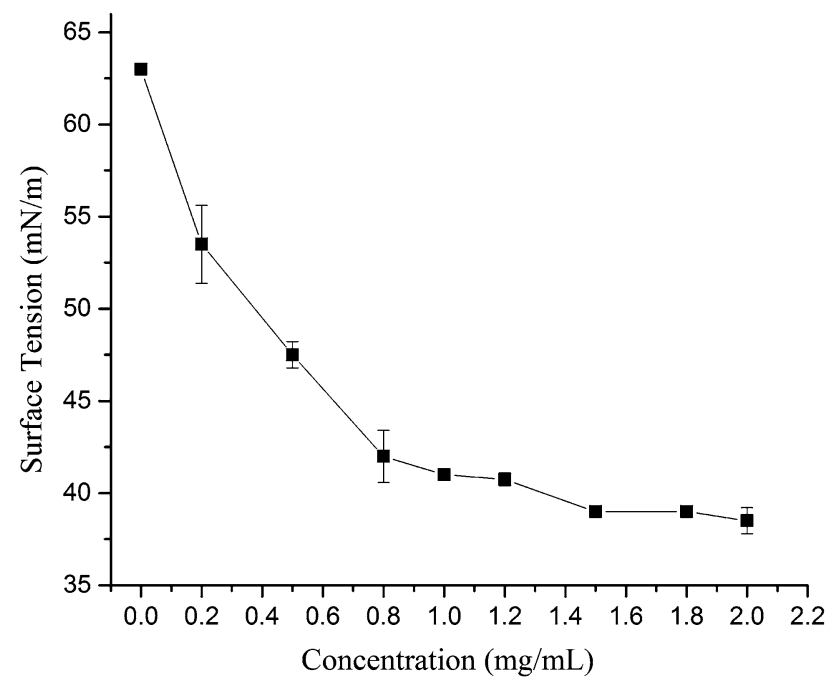

Fig. 3 Surface tension plotted against concentration of crude biosurfactant solution

\section{Surface Tension and Critical Micelle Concentration (CMC)}

Surface tension values $(\mathrm{mN} / \mathrm{m})$ of the medium at 5,7 and 9\% (v/v) glycerol are shown in Fig. 2. The media with 5\% glycerol supplemented with 0.01 and $0.05 \mathrm{mM} \mathrm{MnSO}_{4}$ were able to reduce the medium surface tension by 39 and $38 \%$, respectively.

The surface tension values at different concentrations of crude biosurfactant are shown in Fig. 3. The crude biosurfactant solution at $0.8 \mathrm{mg} \mathrm{mL}^{-1}$ was able to reduce the buffer surface tension from 63 to $42 \mathrm{mN} \mathrm{m}^{-1}$. Crude biosurfactant solution at $1.5 \mathrm{mg} \mathrm{mL}^{-1}\left(1.5 \mathrm{~g} \mathrm{~L}^{-1}\right)$ reduced the surface tension to $39 \mathrm{mN} \mathrm{m}^{-1}$. The surface tension reduction and $\mathrm{CMC}$ value found by Abdel-Mawgoud et al. [27] were $36 \mathrm{mN} \mathrm{m}^{-1}$ and $15.3 \mathrm{mg} \mathrm{L}^{-1}$, respectively. These authors suggest that variations in $\mathrm{CMC}$ values depends on the purity of the surfactin. The CMC values determined in the present study were from a crude biosurfactant. Thus, it may explain the high value of CMC found in this study. In addition, Liu et al. [28] proposed that the number of carbons of the fatty acids chain influence in the CMC and solubility of the surfactin.

\section{Emulsifying Index $\left(\mathbf{E}_{24}\right)$}

The emulsifying power is another important property of the biosurfactants. The emulsifying index of the crude biosurfactant solution against diesel fuel increased from 23.6 to $33.7 \%$, according to the biosurfactant concentration. The highest emulsifying index was $37.7 \%$ at $1.5 \mathrm{mg} \mathrm{mL} \mathrm{m}^{-1}$ of crude biosurfactant solution. Interestingly, concentrations higher than 1.5 did not guarantee high emulsifying index. The crude biosurfactant solution showed properties such as emulsifying power and surface tension reduction that could improve oil recovery processes.

\section{Purification and Chemical Characterisation of the Biosurfactant}

The purified biosurfactant obtained from column chromatography showed a retention factor of 0.5 . The same value of $R f$ was reported by Cho et al. [29]. The IR spectra of

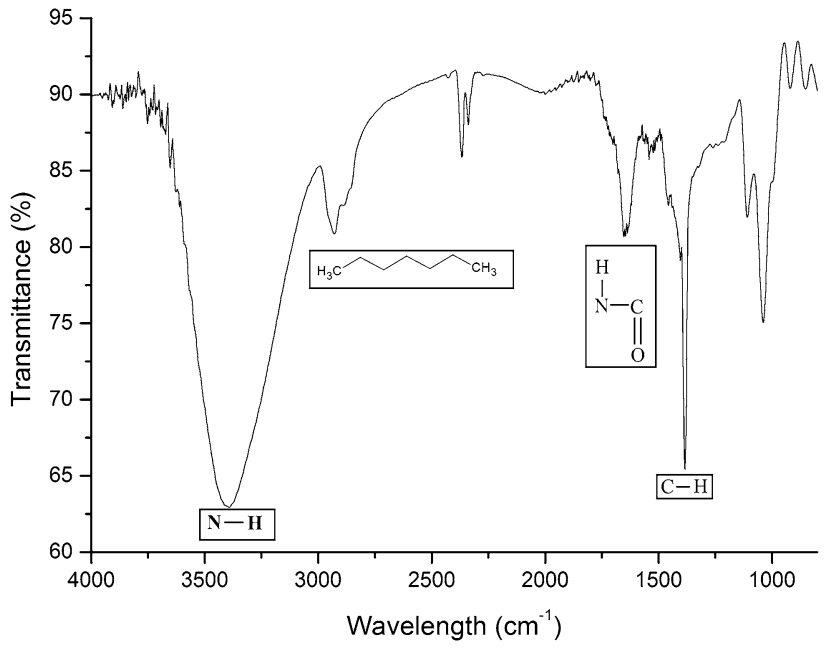

Fig. 4 Infrared spectra of the biosurfactant produced by B. subtilis 


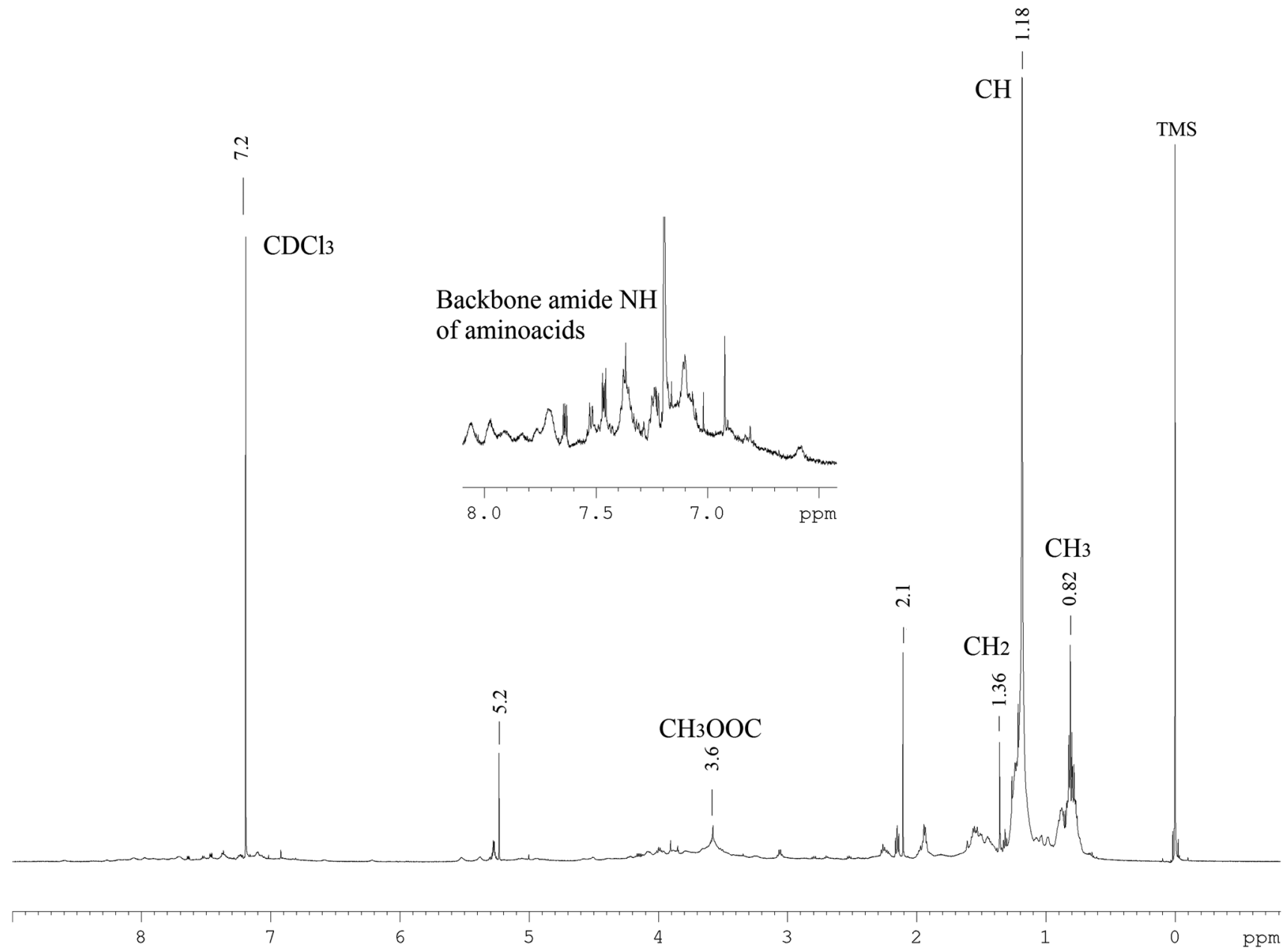

Fig. 5 Nuclear magnetic resonance $\left({ }^{1} \mathrm{H}\right.$ NMR) spectra of the purified biosurfactant obtained in $\mathrm{CDCl}_{3}$ at $25^{\circ} \mathrm{C}$

the biosurfactant indicates the presence of a peptide component at $3398 \mathrm{~cm}^{-1}$ resulting from $\mathrm{N}-\mathrm{H}$ stretching mode as shown in Fig. 4. Bands at 2933 and $1382 \mathrm{~cm}^{-1}$ indicated the presence of an aliphatic chain. The absorbance around $1650 \mathrm{~cm}^{-1}$ belonged to $\mathrm{C}=\mathrm{O}$ stretching vibration of the amide I region [30]. The peak at 1109 is because of $\mathrm{C}-\mathrm{O}-\mathrm{C}$ vibrations in esters $[30,31]$.

Figure 5 shows the ${ }^{1} \mathrm{H}$ NMR spectra as well as their assignments. The assigned peaks in ${ }^{1} \mathrm{H}$ NMR spectra showed similarity among the surfactin spectra described in other studies [5-8, 17-20, 32].

Backbone-amide- $\mathrm{NH}$ groups are in the region from $\delta=7.7$ to $7.0 \mathrm{ppm}$. Signals around $\delta=5.2$ indicated $\mathrm{H} \alpha$ from amino acids, which comprise the hydrophilic moiety. The peaks at $\delta=2.1-0.82 \mathrm{ppm}$ confirmed the presence of a long aliphatic chain, the hydrophobic moiety. A methyl ester proton $\left(\mathrm{CH}_{3} \mathrm{OOC}\right)$ at $\delta=3.6 \mathrm{ppm}$ was observed. Distinct regions identified by IR and ${ }^{1} \mathrm{H}$ NMR spectra presented evidence that the molecule in the study is the biosurfactant, surfactin.

\section{Conclusion}

The crude glycerol from a biodiesel refinery can be a lowcost feedstock for biosurfactant production. The production is superior when compared with similar studies using glucose or LB medium as carbon source. In addition, biosurfactant production by $B$. subtilis can be considered as a safe molecule, because this member of the genus Bacillus is non-pathogenic. Other benefits of the process include the sustainable use of glycerol and the reduction in production costs of a highly useful product. Also, the biotechnological valorisation of crude glycerol makes biodiesel production more sustainable and economically attractive.

Acknowledgements This work was supported by FAPESP [Grant number 2013/13813-0] and RBI- Research Brazil Ireland. 


\section{Compliance with Ethical Standards}

Conflict of interest The authors have declared no conflict of interest.

\section{References}

1. Mulligan, C.N.: Environmental applications for biosurfactants. Environ. Pollut. 133, 183-198 (2005). doi:10.1016/j. envpol.2004.06.009

2. Makkar, R.S., Cameotra, S.S., Banat, I.M.: Advances in utilization of renewable substrates for biosurfactant production. AMB Exp. 1, 1-5 (2011). doi:10.1186/2191-0855-1-5.

3. Yang, F., Hanna, M.A., Sun, R.: Value-added uses for crude glycerol a byproduct of biodiesel production. Biotechnol. Biofuels 5, 1-10 (2012). doi:10.1186/1754-6834-5-13.

4. Pathak, K.V., Keharia, H.: Identification of surfactins and iturins produced by potent fungal antagonist, Bacillus subtilis $\mathrm{K} 1$ isolated from aerial roots of banyan (Ficus benghalensis) tree using mass spectrometry. 3. Biotech 4, 283-295 (2014). doi:10.1007/ s13205-013-0151-3

5. De Faria, A.F., Teodoro-Martinez, D.S., Barbosa, G.N.O., Vaz, B.G., Silva, Í.S., Garcia, J.S., Tótola, M.R., Eberlin, M.N., Grossman, M., Alves, O.L., Durrant, L.R.: Production and structural characterization of surfactin $(\mathrm{C} 14 / \mathrm{Leu} 7)$ produced by Bacillus subtilis isolate LSFM-05 grown on raw glycerol from the biodiesel industry. Process Biochem. 46, 1951-1957 (2011). doi:10.1016/j.procbio

6. Kowall, M., Vater, J., Kluge, B., Stein, T., Franke, P., Ziessow, D.: Separation and characterization of surfactin isoforms produced by Bacillus subtilis OKB 105. J Colloid Interface Sci. 204, 1-8 (1998). doi:10.1006/jcis.1998.5558

7. Baumgart, F., Kluge, B., Ullrich, C., Vater, J., Ziessow, D.: Identification of amino acid substitutions in the lipopeptide surfactin using 2D NMR spectroscopy. Biochem. Biophys. Res. Commun. 177, 998-1005 (1991). doi:10.1016/0006-291X(91)90637-M

8. Liu, X.Y., Yang, S.Z., Mu, B.Z.: Production and characterization of a C15-surfactin-O-methyl ester by a lipopeptide producing strain Bacillus subtilis HSO121. Process Biochem. 44, 1144-1151 (2009). doi:10.1016/j.procbio.2009.06.014

9. Liu, X.Y., Yang, S.Z., Mu, B.Z.: Isolation and characterization of a C12-lipopeptide produced by Bacillus subtilis HSO 121. J. Pept. Sci. 14, 864-875 (2008). doi:10.1002/psc.1017

10. Tang, J.S., Gao, H., Hong, K., Yu, Y., Jiang, M.M., Lin, H.P., Ye, W.C., Yao, X.S.: Complete assignments of $1 \mathrm{H}$ and $13 \mathrm{C}$ NMR spectral data of nine surfactin isomers. Magn. Reson. Chem. 45, 792-796 (2007). doi:10.1002/mrc.2048

11. You, J., Yang, S., Mu, B.: Structural characterization of lipopeptides from Enterobacter sp. strain N18 reveals production of surfactin homologues. Eur. J. Sci. Technol. 117, 890-898 (2015). doi:10.1002/ejlt.201400386

12. Jajor, P., Piłakowska-Pietras, D., Krasowska, A., Łukaszewicz, M.: Surfactin analogues produced by Bacillus subtilis strains grown on rapeseed cake. J. Mol. Struct. 1126, 141-146 (2016). doi:10.1016/j. molstruc.2016.02.014

13. Hazra, C., Kundu, D., Chaudhari, A.: Lipopeptide biosurfactant from Bacillus clausii BS02 using sunflower oil soapstock: evaluation of high throughput screening methods, production, purification, characterization and its insecticidal activity. RSC Adv. 5, 2974-2982 (2015). doi:10.1039/C4RA13261K

14. Liu, Q., Lin, J., Wang, W., Huang, H., Li, S.: Production of surfactin isoforms by Bacillus subtilis BS-37 and its applicability to enhanced oil recovery under laboratory conditions. Biochem. Eng. J. 93, 31-37 (2015). doi:10.1016/j.bej.2014.08.023

15. Nitschke, M., Pastore, G.M.: Production and properties of a surfactant obtained from Bacillus subtilis grown on cassava wastewater. Bioresour. Technol. 97, 336-341 (2006). doi:10.1016/j. biortech.2005.02.044
16. Wei, Y.H., Chu, I.M.: Mn2 + improves surfactin production by Bacillus subtilis. Biotechnol. Lett. 24, 479-482 (2002)

17. Wei, Y.H., Chu, I.M.: Enhancement of surfactin production in iron-enriched media by Bacillus subtilis ATCC 21332. Enzym. Microb. Technol. 22, 724-728 (1998). doi:10.1016/ S0141-0229(98)00016-7

18. Cooper, D.G., Macdonald, C.R., Duff S.J.B., Kosaric, N.: Enhanced production of surfactin from Bacillus subtilis by continuous product removal and metal cation additions. Appl. Environ. Microbiol. 42, 408-412 (1981)

19. Cooper, D., Goldenberg, B. G.: Surface-active qgents from two Bacillus species. Appl. Environ. Microbiol. 53, 224-229 (1987)

20. Makkar, R.S., Cameotra, S.S.: Structural characterization of a biosurfactant produced by Bacillus subtilis at $45^{\circ} \mathrm{C}$. J. Surfact. Deterg. 2, 367-372 (1999). doi:10.1007/s11743-999-0091-6

21. Szymanowska-Powałowska, D.: The effect of high concentrations of glycerol on the growth, metabolism and adaptation capacity of Clostridium butyricum DSP1. Electron. J. Biotechnol. 18, 128-133 (2015). doi:10.1016/j.ejbt.2015.01.006

22. Sousa, M., Melo, V.M.M., Rodrigues, S., Sant'ana, H.B., Gonçalves, L.R.B: Screening of biosurfactant-producing Bacillus strains using glycerol from the biodiesel synthesis as main carbon source. Bioprocess Biosyst. Eng. 35, 897-906 (2012). doi:10.1007/ s00449-011-0674-0

23. Gudinã, E.J., Fernandes, E.C., Rodrigues, A.I., Teixeira, J.A., Rodrigues, L.R.: Biosurfactant production by Bacillus subtilis using corn steep liquor as culture medium. Front. Microbiol. 6, 59 (2015). doi:10.3389/fmicb.2015.00059.

24. Huang, X., Liu, J., Wang, Y., Liu, J., Lu, L.: The positive effects of $\mathrm{Mn} 2+$ on nitrogen use and surfactin production by Bacillus subtilis ATCC 21332. Biotechnol. Biotechnol. Equip. 29, 381-389 (2015). doi:10.1080/13102818.2015.1006905.

25. Shemesh, M., Chai, Y.A.: Combination of glycerol and manganese promotes biofilm formation in Bacillus subtilis via histidine kinase kinD signalling. J. Bacteriol. 195, 2747-2754 (2013). doi:10.1128/ JB.00028-13

26. Al-Wahaibi, Y., Joshi, S., Al-Bahry, S., Elshafie, A., Al-Bemani, A., Shibulal, B.: Biosurfactant production by Bacillus subtilis $\mathrm{B} 30$ and its application in enhancing oil recovery. Colloids Surf. B Biointerfaces 114, 324-333 (2014). doi:10.1016/j. colsurfb.2013.09.022.

27. Abdel-Mawgoud, A.M., Aboulwafa, M.M., Hassouna, N.A.H.: Characterization of surfactin produced by Bacillus subtilis isolate BS5. Appl. Biochem. Biotechnol. 150, 289-303 (2008). doi:10.1007/s12010-008-8153-Z

28. Liu, Y., Koh, C.M.J., Ji, L.: Bioconversion of crude glycerol to glycolipids in Ustilago maydis. Bioresour. Technol. 102, 3927-3933 (2011). doi:10.1016/j.biortech.2010.11.115

29. Cho, S.J., Hong, S.Y., Kim, J.Y., Park, S.R., Kim, M.K., Lim, W.J., Shin, E.C., Kim, E.J., Cho, Y.U., Yun, H.D.: Endophytic Bacillus sp. CY22 from a balloon flower (Platycodon grandiflorum) produces surfactin isoforms. J. Microbiol. Biotechnol. 13, 859-865 (2003)

30. Shao, C., Liu, L., Gang, H., Yang, S., Mu, B.: Structural diversity of the microbial surfactin derivatives from selective esterification approach. Int. J. Mol. Sci. 16, 1855-1872 (2015). doi:10.3390/ ijms 16011855.

31. Das, P., Mukherjee, S., Sen, R.: Antimicrobial potential of a lipopeptide biosurfactant derived from a marine Bacillus circulans. J. Appl. Microbiol. 104, 1675-1684 (2008). doi:10.1111/j.1365-2672.2007.03701.x

32. Pereira, J.F.B., Gudiña, E.J., Costa, R., Vitorino, R., Teixeira, J.A., Coutinho, J.A.P., Rodrigues, L.R.: Optimization and characterization of biosurfactant production by Bacillus subtilis isolates towards microbial enhanced oil recovery applications. Fuel 111, 259-268 (2013). doi:10.1016/j.fuel.2013.04.040 